\title{
Application of Multi-Criteria Analysis on Theatres' Efficiency - Czech and Polish Comparative Case Studies
}

\author{
Jiři Bečica*
}

Roman Varrek

Matgorzata Galecka***

Katarzyna Smolny ${ }^{* * * *}$

\author{
https://doi.org/10.31297/hkju.21.3.5 \\ UDK 351.85:347.786(437.3:438) \\ 351.85:330.13(437.3:438) \\ Original scientific paper/izvorni znanstveni rad \\ Received / primljeno: 27.10.2020. \\ Accepted/prihvaćeno: 25. 6.2021.
}

* Jiří Bečica, Assistant Professor, VŠB - Technical University of Ostrava, Czech Republic (docent, VŠB - Tehničko sveučilište u Ostravi, Češka, email: jiri.becica@vsb.cz)

ORCID: https://orcid.org/0000-0002-6005-9093

** Roman Vavrek, Assistant Professor, VŠB - Technical University of Ostrava, Czech Republic (docent, VŠB - Tehničko sveučilište u Ostravi, Češka, email: roman.vavrek@vsb.cz) ORCID: https://orcid.org/0000-0002-6047-9434

*** Małgorzata Galecka, Assistant Professor, Wroclaw University of Economics and Business, Poland (docentica, Ekonomsko sveučilište u Wrocławu, Poljska, email: malgorzata. galecka@ue.wroc.pl)

ORCID: https://orcid.org/0000-0003-1986-3140

**** Katarzyna Smolny, Assistant Professor, Wroclaw University of Economics and Business, Poland (docentica, Ekonomsko sveučilište u Wrocławu, Poljska, email: katarzyna. smolny@ue.wroc.pl)

ORCID: https://orcid.org/0000-0001-5048-8372 
Institutions (theatres) evaluated in this paper are mediators of an unrepeatable interpretive art and they need funds from public resources of different government levels to ensure their activities. The aim of the present paper is to evaluate the efficiency of theatre management of 93 evaluated public theatres in the Czech Republic and Poland through 11 indicators. The evaluated weights of chosen indicators were determined by the Technique for Order of Preference by Similarity to Ideal Solution (TOPSIS), in combination with the chosen objective method for determining the importance of indicators. From the results it is evident that big multi-genre theatres producing more genres of interpretive art (drama, opera, ballet, musical) with a bigger number of employees had the worst results in both states.

Keywords: culture, public goods, theatres, MCDM methods, TOPSIS, international comparison

\section{Introduction*}

Most entities or activities realised in dramatic art in Poland and the Czech Republic cannot do without subsidies from public sources. The reason behind this funding from public sources is an effort by politicians to ensure public goods in culture for inhabitants that the market cannot ensure in such a politically appropriate range. The contribution is focused on an evaluation of the efficiency of publicly established institutions providing services in the field of interpretive art (theatres) within Poland and the Czech Republic as examples of cultural organisations in central and eastern Europe. A partial aim is to try to answer the hypothesis of whether the focus of the theatre in terms of the operated genre has an effect on the efficiency of organisations in the Czech Republic and Poland, i.e. whether single-genre or multi-genre theatres are more efficient.

The paper seeks to clarify the role and position of professional theatres in Poland and the Czech Republic which provide cultural services in the

* This research was funded by the Student Grant Competition in VŠB - Technical University of Ostrava, grant number SP2021/18; Technological Agency of the Czech Republic, grant number TL01000145. 
field of mixed public goods in culture for the population (if for children's performances, then limited to pure public goods). From the perspective of securing and developing cultural goods, the most important aspect is not profitability, but the preservation of the historical identity of values and the availability of goods for broad sections of the population. From the perspective of the offer of cultural goods, it is important to maintain and develop various theatrical genres and strengthen the cultural identity of the nation through a comprehensive range of services. The private sector will not provide this due to the non-profitability of these services.

Not only in Poland and the Czech Republic, but in other developed democratically controlled states as well, only a small part of cultural entities can gain sufficient funds by their main activity, i.e. entrance fee or additional selling of services. This leads to founders, respected top management of government level (states, regions, or municipalities), entering political agreements to ensure funds for certain kinds of public goods (cultural goods including) in public budgets. It follows that policy decisions on the allocation of funds are not always based on objective methods, but are very often subjective, which is not correct. In the market, the institution providing public goods (net or mixed) would not be able to ensure such goods without funds from public resources; that is found unacceptable in the long term by elected politicians and the public, both non-expert and expert. That is why there are different supported legal statuses for non-profit organisations that ensure public goods for their inhabitants from public resources in most developed countries.

Our article is part of the discussion on public financing of cultural services. Objective criteria in this field are not possible, because of the proper definition of culture and cultural good. The only idea that can be pursued in this field is to seek criteria of fairness, tending to reward merit in the distribution of public resources. Therefore, the authors selected both economic-financial criteria and technical-performance criteria for evaluation. Since it is not possible for non-profit organisations to evaluate their profit, the question of their efficiency arises in many countries, specifically efficiency of provided public resources when realising public goods for inhabitants. Many authors evaluate non-profit organisations in the cultural field across the world. Some examples include Badia and Borin (2012), Cai and Wang (2012), and Charles and Kim (2016). In terms of evaluation of interpretative art services (theatres), research by Bečica (2018), or Galecka and Smolny (2019) is available.

Each of the above-mentioned theses come from an evaluation of non-profit organisations, usually in terms of value for money. Within this concept, 
it is a measurement of the efficiency of different chosen technical and economical indexes by homogenous organisations. The aim of such an evaluation is to gain information on the economy and efficiency of provided public funds that should ensure the fulfilment of predetermined goals. The MCDM method of decision-making allows for a reconciliation of seemingly contradictory priorities, enabling a compromise. This method allows for an assessment of the efficiency of the theatres' activities and whether this assessment can be the basis for the subsidy dimension, and an assessment of the efficiency of public cultural institutions' activities. The authors selected 93 public theatres in Poland and the Czech Republic, which form the backbone network of public institutions providing services in the field of interpretive art.

To fulfil the stated aim, the structure of the paper is as follows: section 2 represents a review of relevant literature dedicated to public goods, then to culture and the provision of cultural goods. Section 3 describes the current situation in culture in the Czech Republic and Poland. It also clarifies the selection of the two countries for comparison. The research methodology is described in section 4 , where we specify the selected indicators, used methods, aim, and the two research hypotheses. Section 5 is processed in three parts. Theatres in the Czech Republic and in Poland are analysed separately $(4.1,4.2)$, and together within one evaluated group (4.3). The results obtained are discussed and compared with the results of other research in the last section, which is followed by the concluding remarks.

\section{Culture and Public or Mixed Goods in the Literature}

A sector of national economies provides public goods to inhabitants in democratically managed states. According to Pestoff (1992), a breakdown of the national economy can be approached: from the perspective of the primary focus of organisations in their activity (profit/non-profit); from the perspective of the organisation founder (public or private); or from the perspective of the organisation's anchor (working formally or informally) according to legislation. This breakdown of the national economy allows some combinations on how to ensure different goods and services for inhabitants.

The profit sector should be funded by resources gained from selling goods of the profit sector entities for a market price created by supply and demand on the market. If it is not possible to ensure the market price through 
certain services, the non-profit sector takes up the task of ensuring them, where the aim is not to gain profit but benefits. Funds needed for organisations' activities are necessary to ensure thorough redistribution processes from national, regional or local public budgets. This has been stated by many authors, the first being Musgrave (1959). Peková (2011) states that if one sector fails when providing needs for inhabitants, the role of the other increases. In this case, instead of providing services that are neither enough nor ensured to inhabitants in the market (quality and quantity), services can be offered to inhabitants by the public or civil sector (non-state non-profit sector) in democratically controlled countries using public resources.

The issue of goods was already mentioned in economic literature in the thesis by Pareto and Schwier (1927), in the context of the neo-classical theory and Pareto's optimum. However, the first definition of public goods is attributed to Samuelson (1954), which was extended by Musgrave (1959) and discussed by, for instance, Samuelson and Nordhaus (2010) or Stiglitz and Rosengard (2015). According to Stiglitz (1997), the imbalance in the market is the result of the failure of private companies who follow their interests and usually only try to maximise profits for their owners and not create benefits for the whole society. The private sector should have the main role in providing services in democratic market-controlled countries, but its every failure leads to the development of the public sector. The public sector then satisfies the needs of the society and its inhabitants, usually by providing net or mixed public goods and services. Funding of the services is more or less dependent on the resources from the public budgets of different government levels (states, regions, municipalities); elected representatives (public choice) make decisions regarding the funds, and they are subjected to public scrutiny and managed by public administration.

The notion of culture first appeared in France in the $17^{\text {th }}$ century. It derives from the Latin verb colo (colere, colui, cultum) which means to grow and agriculturally occupy. To date, the spirit of the notion of culture is not clearly designated and is an issue under expert discussion across the globe.

In the broadest definition (Dvořák, 2004), culture is a mixed public good. Its production and consumption are in the interest of developed states, but states do not determine its specific composition. Cultural goods are characterised by their scarcity and value in use. These two characteristics form the basis of economic value. It is difficult to set a value to the use of cultural goods because the value of use is different for different users. Since this problem leads to extremes when financing the production of competent cultural goods, the result can be that some goods are underestimated and some overestimated. 
In many developed countries, providing cultural goods is ensured on the basis of a binding document on the government level, the so-called "cultural policy" of a state. The document usually relates to other cultural documents at the national level (e.g. UNESCO) and contains the main global goals of the country, regions, or municipalities in the field of directing culture. Activities in culture most often focus on the development and conservation of cultural heritage, increasing efficiency in the culture field and cultural awareness of inhabitants as a result. The involved cultural policy is a set of methods, processes, tools, and measures for reaching specific goals in the field of culture and mass media. Its purpose is to constantly develop a free, diverse cultural life for all its inhabitants and thereby contribute to the cultural treasury of humanity. On the lower level of government (regions, municipalities), the fulfilment of a valid cultural policy of the national level is declared by politicians. Funds are provided according to such a document to ensure the functioning of a specific cultural organisation or given fields of culture (e.g. musical art, dramatic art, public media, and others). From an economic standpoint, the cultural policy of a state is how the level of the state (regions or municipalities) ensures and influences the production of cultural goods and their consumption, too.

According to Dostál and Kislingerová (2012), cultural policy has developed over many years not only in the Czech Republic but in Poland as well. Moreover, the right to access cultural assets itself is guaranteed in The Charter of Fundamental Rights and Freedoms. The respective ministries of culture guarantee cultural policy and define basic functions of the cultural policy in Poland and the Czech Republic. Within the guarantee of the protection of freedom of creation for artists and art-makers, there is a guarantee of equality in accessing cultural assets or creating conditions for the realisation of cultural activities of inhabitants.

\section{The Description of the Cultural Situation in the Czech Republic and Poland}

The aim of this study is to identify the efficiency of 93 public theatres' management in Poland and the Czech Republic using 11 indicators (five technical, six financial) in order to determine whether the efficiency in the field of theatre is the same or different.

A partial aim is to try to answer the hypothesis of whether the focus of the theatre in terms of the operated genre has an effect on the efficiency of 
organisations in the Czech Republic and Poland, i.e. whether single-genre or multi-genre theatres are more efficient.

The evaluation of theatres in the Czech Republic and Poland is based on several assumptions, such as: the origin of the first stone theatre buildings in both states dates back to the end of the $18^{\text {th }}$ century. The growth of this field of art was recorded during the $19^{\text {th }}$ and especially in the first half of the twentieth century, when most of the theatre organisations evaluated below were established; both states went through a period of occupation before World War II and the subsequent socialist establishment, which applied a specific system of administration and management of cultural institutions; in the 1990s, there was a drastic political and economic change in both states, which was also reflected in the approach to cultural creation and the system of establishment and financing theatres from the central level of the state; founding competencies were transferred in both states primarily to the regional level (regions in the Czech Republic, voivodeship in Poland), and also to the local level (municipalities in the Czech Republic, gminy in Poland). There are no specific studies as to why in one of the theatres the competences were transferred to the regional level and in another to the local level. It is also not clear whether the produced genre of the theatre affects the efficiency of the organisation; it is also possible to mention the joint action of the states within the Visegrad Group in a number of matters and the associated long-term cooperation of both states in selected areas, which, however, cannot include the area of culture we are currently examining; it is also possible to mention the professional knowledge of the authors in terms of the applied conditions in the cultural field of the Czech Republic and Poland.

Primary data for the comparison of evaluated organisations within the Czech Republic and Poland were obtained from official sources of different levels. According to the decision of the founder, economic and technical information may not be published in the statistics at all. Economic information on the management of individual theatres is published with a delay of approximately two years. Technical information is not normally available for individual theatre organisations and has been provided to the authors on request. The year 2015 was chosen because the data availability for the evaluated sample was the highest. A large number of organisations did not agree to the publication of values in subsequent (new) years, and these would have to be excluded from the comparison, which would reduce the credibility of the processing. In the Czech Republic, these are all the theatres that are established by the public sector in the legal form of a non-profit organisation and have permanent employees in an em- 
ployment relationship - not just contracted for a specific play or who are the founders of a theatre ${ }^{1}$ without a professional ensemble. In Poland, the authors selected 67 public theatres which form the backbone network of public institutions providing services in the field of interpretive art.

The inhomogeneity of the evaluated set of theatres is apparent only at first sight. Poland is about 3.5 times larger in population than the Czech Republic, which corresponds to the number of established professional theatres that carry out their activities for the audience.

A common feature of the theatres compared in Poland and the Czech Republic is the existence of a minimum of one professional ensemble within institutions that produce one or more genres of interpretative art (drama, opera, ballet, musical, puppet, and other), and their founder is a public officer at the level of states, regions, or municipalities. The evaluated theatres from the Czech Republic are members of the Association of Professional Theatres of the Czech Republic. As for Poland, in the file there are evaluated professional theatres established by regions or municipalities with more than a hundred thousand inhabitants.

The following assessment carried out was not easy, because during the process it was necessary to deal with different kinds of information. Authors concluded that these, to a certain extent, are influenced by the state of the discloser of information according to the legal form of the theatre in a given state. In terms of the difference between the reported profit and loss account and information stated in annual reports of individual theatres, contributory organisation, public service company, trading company, or limited company can be given as examples. Despite all these deficiencies, the authors of the paper tried to select not only economic-financial indicators (IF 1-6), but also technical-performance indicators (IT 1-5) to compare professional theatres of Poland and the Czech Republic, which has enabled a multi-criteria evaluation of theatres using the selected mathematic-statistical method described below in Section 3.

\subsection{Characteristics of the Theatrical Art in the Czech Republic}

Statistical data for the Czech Republic were drawn from summary characteristics of Czech theatres from the National Information and Advisory

${ }^{1}$ In the Czech Republic, a legal entity (theatre) producing at least 20 theatrical performances per year but not establishing a professional theatre ensemble. 
Centre for Culture (NIPOS), and from the data of the Czech Statistical Office (ČSÚ) in 2015. Economic indicators were drawn from the Informative Portal (IISSP) of the Ministry of Finance of the Czech Republic and from the profit and loss account of the evaluated theatres in 2015. There are 26 established Czech public theatres with the legal form of a contributory organisation or public service company evaluated within the file. The theatres are evenly distributed throughout the Czech Republic and they produce dramas, musicals (musical and operetta), opera, ballet, or puppet performances. Their common feature is also the fact that they are members of the Association of Professional Theatres in the Czech Republic, establishers of at least one professional ensemble, and operate on the theatrical scene at a minimum. Their founders are municipalities with more than thirty thousand inhabitants (LAU 21), then self-governing regions (NUTS 3), and the state (Ministry of Culture of the Czech Republic).

Cultural creation in the Czech Republic (according to a statistical survey) overcomes one record after the other (NIPOS 2015). Vrabková and colleagues (2017) state that cultural organisations of the Czech Republic are established in a different legal manner and their revenue independence is dependent on a number of factors, such as the type of service provided within culture, legal form or nature of the founder (public, private). She further notes lack of efficiency of most cultural institutions that is, within the Czech Republic, the result of excess supply in the market and insufficient amount of demand for culture on the demand side. She also states low self-sufficiency of own funds of most cultural organisations necessary to ensure complete operation from the view of funding. Libraries $(8.31 \%)$, followed by galleries $(16.48 \%)$, and then theatres $(27.21 \%)$ have the lowest self-sufficiency among publicly established cultural organisations in the Czech Republic. It follows from the data given above that publicly established cultural organisations in the Czech Republic are significantly dependent on the funds of their founder, most often municipalities' or regions' councils, or the state (Ministry of Culture of the Czech Republic). The number of entities that operate theatrical activity in the Czech Republic has been stable over a long time. There was a total of 155 institutions with different legal personalities (theatres) in the Czech Republic in 2015. They cumulatively operated 180 stabile theatrical scenes. Currently, there is no special law in the Czech Republic that is valid only for theatres and provides rules for operating them. Theatres are governed by a valid legal system, that is, valid for the chosen legal form of organisation functioning. The most common legal form of publicly established theatres is a contributory organisation. From the given number of theatrical insti- 
tutions in the Czech Republic, 25\% (40) were founded by a public entity (state, region, municipality), making contributory organisation the most common legal form. The remaining $75 \%$ were established by a private entity in a different legal form (limited liability company, joint-stock company, public service company etc.).

There were 28,500 performances offered by theatres and about 42,000 seats in the Czech Republic that were evaluated in 2015. Visitor arrivals grew and kept the quality of the European standard, i.e. 6.2 million visitors. There were about 595 theatre visitors per one thousand inhabitants in the Czech Republic in 2015. The percentage of audience is different according to a number of factors; however, it is about $80 \%$ on average. The highest number of visitors recorded by dramatic performances is realised the most in the Czech Republic.

About 7,000 people are employees in the Czech theatres, and about 13,000 are employees based on other employment relationships and contractual links. Wages in the theatrical field account for only $7.1 \%$ of the total volume of all realised wages in the Czech Republic. The average wage of theatre employees was at the level of EUR 800 (CZK 19 922) in 2015. From the total number of theatre employees, $40 \%$ are recognised in statistics as "unknown character of profession", i.e. independent actors and others that are not typically classified in the field of professional employees. The other $30 \%$ of employees are volunteers, and only $30 \%$ of employees are either professional actors or are recognised in a different profession of cultural character.

\subsection{Characteristics of the Theatrical Art in Poland}

Evaluated Polish public theatres (drama, music, puppet) have also been founded by municipalities (LAU 2) with more than one hundred thousand inhabitants, and voivodships (NUTS 3), according to the Nomenclature of Territorial Units for Statistics (NUTS). Data for evaluation were obtained from individual questions focusing on financial accounts and factual reports of cultural institutions in 2015. The examined sample is composed of 67 public theatres, of which 46 are operated by municipalities, and 21 by regions. A common feature is also the fact that they are founders of at least one professional ensemble and operate a minimum of one theatrical scene. Since it was not possible to precisely diagnose all theatre institutions at the level of economic-financial and technical-performance indicators (e.g. availability of basic information as to the num- 
ber of visitors, number of seats in the auditorium, etc.), not all publicly established theatres in the Czech Republic and Poland have been taken into account. Their selection is evenly represented through the whole territory of Poland according to the stated indicators.

Development of the theatrical art in Poland was influenced, for a long time, by communist ideology that was the same for a number of middle European states. Public theatres served different purposes during different periods in a post-war state. Besides their basic function, which was propagating and ensuring equal access to culture for inhabitants, theatres often served as indirect politicians and fulfilled ideological purposes including opinions that influence inhabitants.

New scenes were progressively opened in the after-war period and the number of theatres almost doubled in Poland. Private ownership was repressed and the system of theatres was decentralised into public hands. All important decisions were made at the central level through the Ministry of Culture and Art (choice of director, hiring of actors, repertoire, premiere plans, etc.). Theatres worked based on the Decree on State Enterprises, 1950; this meant that they did not significantly differ from factories or mines according to the law. The development of theatrical art in Poland, as in the Czech Republic, was influenced by the communist ideology for a long time - as it was for many Central European countries. Theatre companies changed into art institutions only in 1984.

Currently, theatres in Poland operate on the basis of the Act on Organising and Running Cultural Activities (UOK) that was adopted in 1991. This law created a legislative framework for cultural funding in a democratically controlled Polish economy. The law introduced the concept of "cultural institutions" (theatres, museums, libraries, etc.) and allowed them free establishment. Nowadays, public cultural institutions are founded by the Ministry of Culture or other central or local authorities (regions, municipalities) in Poland. Public founding of a theatre provides necessary property to the institution, and the institution gains legal personality when registering in the public register.

Polish cultural policy had been associated with censorship, centralistic policy of the ruling party, lack of freedom of speech and limited art creation until 1989, when the country gained independence after socio-economic transformation. A system of culture following the pattern of west-oriented economies was preferred and the system of public funding of cultural institutions in Poland gained characteristics of both the French model, which grants cultural freedom to inhabitants under the Constitution, and the German model, where most cultural institutions were transferred into 
the hands of local authorities (regions, municipalities). They are, therefore, the founders of most non-profit cultural institutions and provide for them financially.

Nowadays in Poland, most theatres are established as "non-profit" in public hands and are located within urban centres. In 2015, there were 133 theatres in Poland, making them fewer than in the Czech Republic despite the number of inhabitants being almost four times higher. Seventy percent of the total volume of resources from the founder's budget, i.e. public budget of the state and budgets of regions and municipalities, fund theatres. The inhabitants' expenditure in the cultural field is relatively low and accounts for only about $3.7 \%$ of the total expenditure of Polish households. Nevertheless, it can be stated that theatres are less dependent on founder's funds in comparison with other cultural institutions such as museums, galleries, or libraries where income self-sufficiency of institutions accounts for $20 \%$ of the total volume necessary for operating a given institution.

\section{Research Methodology}

The MCDM method of decision-making allows for a reconciliation of seemingly contradictory priorities, giving the opportunity to find a compromise. The research question is whether this method allows for an assessment of the efficiency of the theatres' activities and whether this assessment can be the basis for the subsidy dimension and an assessment of the efficiency of public cultural institutions' activities.

As mentioned above, the aim of this study is to identify the efficiency of 93 public theatres' management in Poland and the Czech Republic in 2015 using 11 indicators ( 5 technical, 6 financial). A partial aim is to show whether the choice of genre addressed by the institution (single-genre vs. multi-genre theatres) affects the efficiency of organisations. To verify this aim, two research hypotheses (RH) were defined as follows:

RH1: We assumed that there are statistically significant differences in the efficiency of management of multi- and single-genre public theatres in the Czech Republic (Poland) using the MW-TOPSIS technique.

RH2: We assumed that there are no statistically significant differences in the efficiency of public theatres' management in the Czech Republic and Poland using the MW-TOPSIS technique. 
An evaluation of the results is realised using more mathematical-statistical methods where we can classify them using:

Mann-Whitney test (W)

$$
U^{\prime}=n_{y} n_{x} \frac{n_{y}\left(n_{y}+1\right)}{2}-R_{y}, U=n_{y} n_{x}-U^{\prime}
$$

where: $n_{x}=$ number of observations of the $\mathrm{x}(\mathrm{th})$ sample

$n_{y}=$ number of observations of the $\mathrm{y}(\mathrm{th})$ sample

$R_{y}=$ sum of the order of the $\mathrm{y}(\mathrm{th})$ sample

$\mathrm{U}, \mathrm{U}^{\prime}=$ test statistics

Levene's test (LE)

$$
\mathrm{W}=\frac{(N-k)}{(k-1)} \frac{\sum_{i=1}^{k} N_{i}\left(Z_{i}-Z_{. .}\right)^{2}}{\sum_{i=1}^{k} \sum_{j=1}^{N_{i}}\left(Z_{i j}-Z_{i}\right)^{2}}
$$

where: $k=$ number of values of the observed categorical variable

$N=$ number of observations

$N_{i}=$ number of observations of the $\mathrm{i}(\mathrm{th})$ sample

$Y_{i j}=$ measured value of the $\mathrm{j}(\mathrm{th})$ unit of the $\mathrm{i}(\mathrm{th})$ group

$Y_{i}=$ average value of the $\mathrm{i}(\mathrm{th})$ group

$\tilde{Y}_{i}=$ median of the $\mathrm{i}(\mathrm{th})$ group

$\bar{Z}_{\text {.. }}=$ average of groups $Z_{i j}$

$Z_{i .}=$ average $Z_{i j}$ for the $\mathrm{i}(\mathrm{th})$ group

Kolmogorov-Smirnov test $(\mathrm{K}-\mathrm{S})$

$$
D_{n_{1}, n_{2}}=\sup \left|F_{1, n_{1}}(x)-F_{2, n_{2}}(x)\right|-\infty<x<\infty
$$

where: $F_{1, n_{1}}(x)=$ empirical distribution function of the first sample

$F_{2, n_{2}}(x)=$ empirical distribution function of the second sample

All calculations and analyses are realised in MS Excel, Statistica 13.4, and Statgraphics XVIII.

\subsection{TOPSIS as a Method of Multi-Criteria Evaluation}

According to Čereška and colleagues (2018), the main idea of multi-criteria decision-making (MDCM) methods is the joining of evaluation criteria values and their weights to single evaluation characteristics. There are several tools in MCDM, used by many authors like Guarini and colleagues (2018), Zolfani and colleagues (2018), Noryani and colleagues 
(2018), Zavadskas and colleagues (2018) etc., to select the best variant based on several criteria. TOPSIS is a MCDM method with a high utilisation rate of solving decision-making problems of different characteristics. Zavadskas and colleagues (2016) classified it as the second most used and provided alternatives including analytical hierarchy process (AHP), analytic network process (ANP), preference ranking organisation method for enrichment evaluation (PROMETHEE), and elimination and choice expressing the reality (ELECTRE) (see Wang \& Poh, 2017; Aouadni, Rebai $\&$ Turskis, 2017). The results can be described simply as values calculated based on the shortest distance to a positive ideal solution (i.e. variants that can be real but fictitious as well), and the longest distance to a negative ideal solution. This method is tackled more deeply in Shih, Shyur \& Lee (2007), Seyedmohammadi and colleagues (2018), Vavrek and Bečica (2020a), and is calculated as follows.

Firstly, a data matrix is created (it ranks alternatives according to the respective pre-identified criteria):

$$
\mathrm{D}=\left(\begin{array}{ccccc} 
& X_{1} & X_{2} \ldots & X_{j} \ldots & X_{n} \\
A_{1} & x_{11} & x_{12} \ldots & x_{1 j} \ldots & x_{1 n} \\
A_{2} & x_{21} & x_{22} \ldots & x_{2 j} \ldots & x_{2 n} \\
\vdots & : & : & \vdots & : \\
A_{i} & x_{i 1} & x_{i 2} \ldots & x_{i j} \ldots & x_{i n} \\
\vdots & \vdots & : & \vdots & : \\
A_{m} & x_{m 1} & x_{m 2} \ldots & x_{m j} \ldots & x_{m n}
\end{array}\right)
$$

where: $A_{i}=\mathrm{i}($ th) alternative,

$x_{i j}=$ value of the $\mathrm{j}($ th) criterion reached by the $\mathrm{i}($ th) alternative

In the next step, this data matrix is standardised/normalised using the formula

$$
r_{i j}=x_{i j} / \sqrt{\sum_{j=1}^{j} x_{i j}^{2}}
$$

where: $r_{i j}=$ normalised value of the $\mathrm{j}($ th) criterion

$x_{i j}=$ value of the $\mathrm{j}($ th) criterion reached by the $\mathrm{i}(\mathrm{th})$ alternative

The acquired data matrix is multiplied by the weights of the relevant criteria using the formula: 


$$
v_{i j}=w_{i j} * r_{i j}
$$

where: $v_{i j}=$ weighted normalised value

$w_{i j}=$ criterion weight

$r_{i j}=$ normalised value

Positive Ideal Solution (PIS) and Negative Ideal Solution (NIS) are identified:

$$
H_{j}=\max \left(w_{i j}\right), D_{j}=\min \left(w_{i j}\right)
$$

where: $H_{j}=$ PIS

$$
D_{j}=\text { NIS }
$$

The distance of each real alternative from thus obtained PIS and NIS can be calculated based on the following formula:

$$
d_{i}^{+}=\sqrt{\sum_{j=1}^{k}\left(w_{i j}-H_{j}\right)^{2}}, d_{i}^{-}=\sqrt{\sum_{j=1}^{k}\left(w_{i j}-D_{j}\right)^{2}}
$$

where: $d^{+}=$distance from PIS

$$
d^{-}=\text {distance from NIS }
$$

The key criterion according to which the order of alternatives is arranged represents the relative distance to PIS, which takes both identified distances from the previous step into consideration by means of the formula given below.

$$
c_{i}=\frac{d_{i}^{-}}{d_{i}^{-}+d_{i}^{+}}
$$

where: $c_{i}=$ relative distance to PIS

An important aspect of evaluation is setting the importance, i.e. weight of selected indicators. While Keršuliene, Zavadskas and Turskis (2010) divide these approaches into four basic groups as follows: subjective, professional, objective, and integrated (a combination of previous approaches), there are more approaches to determining them.

According to Vavrek and Bečica (2020b), the first group, created by subjective methods, reflects the personality and individuality of decision makers who, according to their own opinions (mostly professional), set the importance of individual indicators. Expert evaluation, i.e. evaluation of a 
group composed of larger or smaller numbers of professionals in a given sphere, creates the second group of methods (e.g. Fuller method, Fuller triangle). The third group, created by objective methods, assigns the weights of individual indicators based on a predetermined mathematical model which is unique for every method, without any influence by decision makers on the results (weight is given by the characteristics of the data). Decision makers influence the results only by choosing the method. We chose the MW (Mean Weight) method, the simplest method of the three when weights of each indicator are the same, for evaluating the basic set of theatres in the Czech Republic and Poland (see Singla, Ahuja \& Sethi, 2018 or Vavrek, 2019).

\subsection{Characteristic of the Selected Indicators}

We worked with a bigger number of indicators in the first phase, which came into consideration for the realisation of the multi-criteria evaluation of basic files of 93 publicly established theatres in Poland and the Czech Republic (see Appendix A). Because of their duplicate informative capability based on research by local authors (Ardielli \& Bečica, 2018; Galecka \& Smolny, 2019), we approached with a selection of 11 indicators, of which 6 are economic-financial indicators and 5 are technical-performance indicators. The concrete selection of evaluated indicators is shown in Table 1.

Table 1: Final selection of evaluated indicators

\begin{tabular}{|c|c|c|}
\hline \multicolumn{2}{|r|}{ Indicator } & Group \\
\hline IT1 & Number of seats & \multirow{5}{*}{$\begin{array}{l}\text { Technical } \\
\text { indicators }\end{array}$} \\
\hline IT2 & Number of scenes (stages) & \\
\hline IT3 & Number of shows & \\
\hline IT4 & Number of premieres & \\
\hline IT5 & Number of viewers (in thousands) & \\
\hline IF1 & Total revenues (in mil. EUR) & \multirow{6}{*}{$\begin{array}{l}\text { Financial } \\
\text { indicators }\end{array}$} \\
\hline IF2 & Total costs (in mil. EUR) & \\
\hline IF3 & Own revenues (in mil. EUR) & \\
\hline IF4 & Subsidies all (in mil. EUR) & \\
\hline IF5 & Labour costs (in mil. EUR) & \\
\hline IF6 & Energy consumption of the main activity (in mil. EUR) & \\
\hline
\end{tabular}

Source: Authors. 
Given the situation already mentioned, a theatre, as an entity operated by public government for providing services for inhabitants, is not (respectively should not be) established, by its very nature, for the primary purpose of gaining profit or maximising its own value. We divided the observed indicators of evaluated institutions into two groups as follows: group 1 - indicators showing technical performance; group 2 - indicators showing financial performance.

Despite the above mentioned, we believe that entities of public administration have to comply with certain rules of financial discipline. These rules are reflected in the law pertaining to working with public funds that should be used economically, efficiently, and effectively. For this reason, we ranked own income or wage (personnel) costs among the observed indicators. Conversely, a theatre provides a public good that is difficult to measure technically. Within a complex evaluation of such entities, it is also suitable to adhere to the quantity of a provided good. We recorded this by observing the number of seats or realised performances.

Indicators showing technical performances and characterising them into professional activity of theatres to a certain extent were drawn from annual individual reports. The chosen financial-economic indicators were converted from Czech crowns and Polish zloty based on a rate decided by the Central Polish Bank and a unit was selected. Due to the position of Poland and the Czech Republic in Europe, euro proves to be better for international comparison.

We consider that it is possible to evaluate the performance of theatres on the basis of such a created composition of indicators by multi-criteria analysis. This helps to recommend concrete precautions to evaluate theatres or the whole evaluated group of entities on the basis of obtained results. Within the selected MCDM (multi-criteria decision making), evaluation plays an important role of setting importance to individual evaluated indicators.

\section{Results}

The results of realised analyses are processed within three individual sub-chapters or parts. The results of each part respond to one of the two research hypotheses set out above (RH1, RH2). The first two parts are focused on the evaluation of theatres at the national level, i.e. evaluation of the theatres in the Czech Republic (RH1a), and in Poland (RH1b). 
In the third part, attention shall be paid to the comprehensive results of Czech and Polish theatres within one evaluated group (RH2).

\subsection{Evaluation of Theatre Performance in the Czech Republic}

Based on the analysis realised, we can conclude the minimum variation margin at the level of 0.071 relative distance to PIS alternative (Figure 1). These results can be supported by the selected moment characteristics, for example standard deviation $\left(\mathrm{s}_{\mathrm{CZ}}=0.017\right)$, coefficient of variance $\left(\mathrm{v}_{\mathrm{CZ}}\right.$ $=3.278 \%)$, or sharpness $(\beta=3.080)$.

Figure 1: Results of the multi-criteria evaluation of the Czech theatres

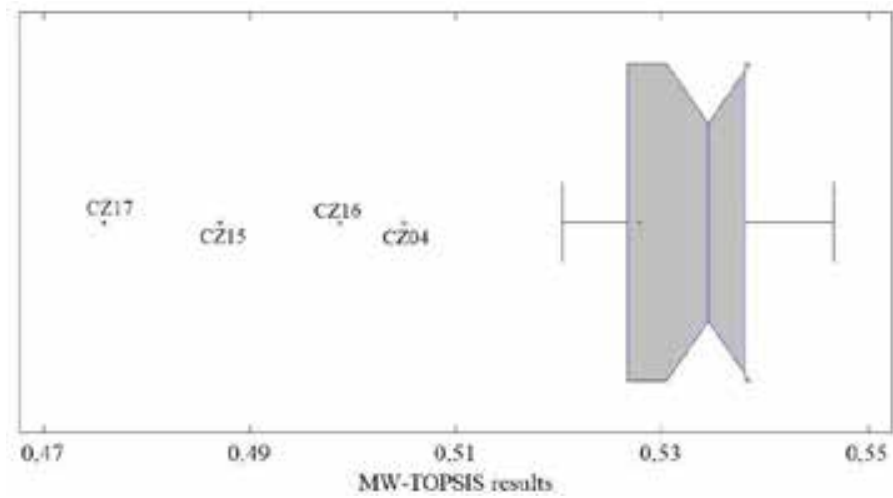

Source: Authors.

Within the evaluation, significant differences can be seen in evaluating individual theatres, especially the ones placed at the end of the ranking. The difference between the best evaluated couple of theatres, i.e. Divadlo Př́bram (CZ06) and Městski divadla pražská (CZ10), is more than ten times smaller than the difference between the four worst multi-genre evaluated theatres in the file - Divadlo J. K. Tyla Plzeñ (CZ04), Národni divadlo Moravskoslezské Ostrava (CZ16), Národni divadlo Brno (CZ15), and the biggest and the most known theatre institution Národni divadlo Praba (CZ17). Financial indicators (IF4 - IF6) had a basic impact on the evaluation, where the last four theatres were always ranked the last from the total file. The ranking of these theatres at the end of the evaluated file can be caused by the nature of the scope of produced art, where 
all mentioned theatres are founders of a larger number of art ensembles producing different genre forms (drama, opera, ballet, musical), operate more buildings (scenes) compared to other theatres, and produce more new performances (premieres).

A larger number of employees (not only actors, but operating employees, too) connect all these matters and it negatively influences the volume of realised wages from the total volume of the theatres' budgets. Within the evaluated file of Czech theatres, there are better total results connected to lower values of total costs (IF2), provided subsidy (IF4), personnel costs (IF5) and energy consumption (IF6). We can also mark better evaluated theatres as those with a lower number of premieres (IT4), usually focused on one interpretative genre, and not requiring such financial resources for realisation. Most often, it is a production of drama performances or puppet performances. The theatres mentioned usually also support operating only one building (scene) with a lower number of seats, which means realising performances with a lower number of personnel, i.e. lower volume of wages.

Figure 2: Comparison of the results of the multi-criteria evaluation of the Czech theatres (single-genre vs. multi-genre)

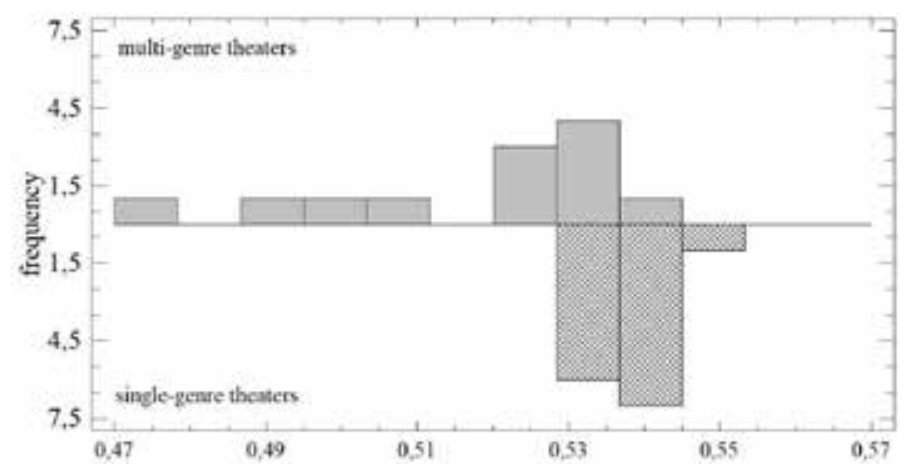

Source: Authors.

The differences between single-genre and multi-genre theatres are illustrated in Figure 2. We can see a difference in the medians $(\mathrm{W}=155 ; \mathrm{p}<$ $0,01)$, in the distribution functions (K-S $=0,845 ; \mathrm{p}<0,01)$, and also in the variance $(\mathrm{LE}=23,870 ; \mathrm{p}<0,01)$. Based on this information, we can partially confirm the research hypothesis (RH1), i.e.,there are differences in the efficiency of public theatres' management of multi- and single-genre theatres in the Czech Republic. 


\subsection{Evaluation of Theatre Performance in Poland}

The variation margin of the results of the multi-criteria evaluation of theatres in Poland shows higher variability of total results $(R=0.317)$. It is considered, by the authors of the paper, that outliers and extreme values of some evaluated theatres can be noticed on both sides of the box fence (Figure 3). A confirmation of this statement is the high degree of result sharpness and their concentration on the mean $(\gamma=15.754)$.

Figure 3: Results of the multi-criteria evaluation of the Polish theatres

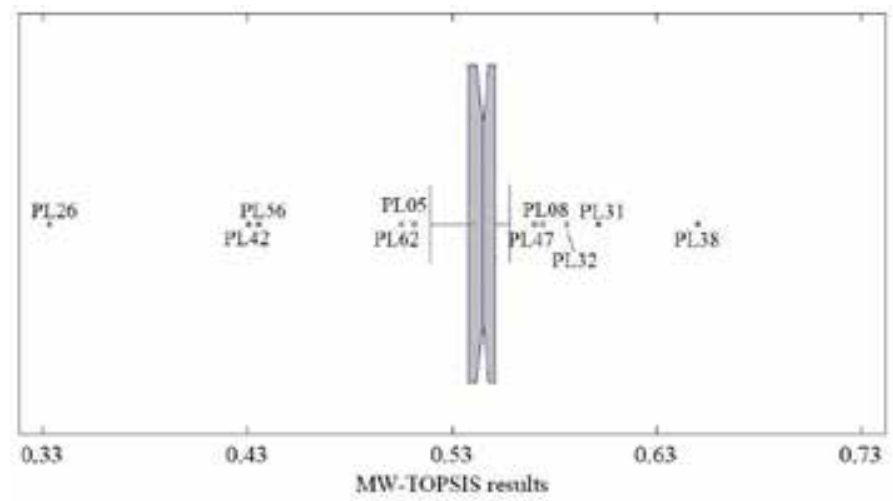

Source: Authors.

As mentioned above, observing significant differences in the evaluation is possible in both groups of the best and worst evaluated Polish theatres. The best evaluated theatre is Teatr Muzyczny Roma (PL38), followed by Pótnocne Centrum Sztuki Teatr Komedia (PL31) and Teatr Kwadrat (PL32). On the other side, with a value of 0.333 (relative distance to PIS alternative, i.e. evaluation MW-TOPSIS), Capitol (PL26) was placed last. Other institutions only had slightly better positions, specifically Teatr Syrena (PL42), and Teatr Wielki v Łodzi (PL56).

It can be noted that, in the case of Polish theatres, better overall evaluation is connected to a lower rate of provided subsidies (IF4), personnel costs (IF5), or energy consumption (IF6) - but lower in rate than Czech theatres. Better evaluated theatres managed to address a larger number of visitors, given the size of the auditorium and the Polish market - which is about three and a half times larger in the number of inhabitants than the Czech Republic. 
Figure 4: Comparison of the results of the multi-criteria evaluation of the Polish theatres (single-genre vs. multi-genre)

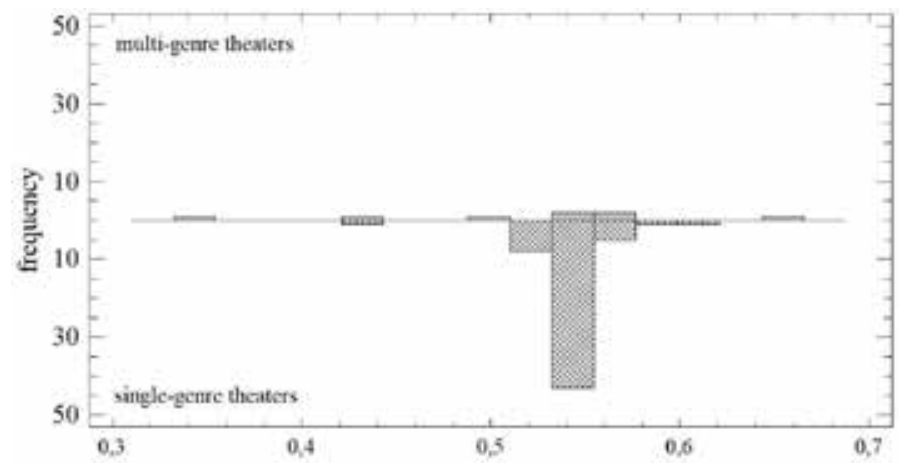

Source: Authors.

The differences between single-genre and multi-genre theatres are described based on Figure 4. We can see no difference in the medians (W $=232 ; \mathrm{p}=0,946)$, in the distribution functions $(\mathrm{K}-\mathrm{S}=0,381 ; \mathrm{p}=0,258)$. The differences are confirmed only in the variance $(\mathrm{LE}=37,556$; $\mathrm{p}<$ $0,01)$. Based on this information, we cannot confirm the research hypothesis (RH1), i.e. there are no differences in the efficiency of public theatres' management of multi- and single-genre theatres in Poland.

\subsection{Comprehensive Evaluation of Czech and Polish Public Theatres' Performance}

When evaluating Czech and Polish theatres within one file, a reduction in absolute can be recorded as shown in Figure 5. These small differences reiterated the high concentration around the mean, specifically around the average at the level of 0.514 , the respective median being 0.517 .

The theatres in Poland placed, within the total evaluated file, both first (PL38 - Teatr Muzyczny Roma), and last (PL 26 - Capitol). Overall, there were 93 evaluated theatres within which 12 can be marked as different. Polish theatres have majority representation in this group, which can be partly attributed to their larger number within the evaluated file (see Figure 6). 
Figure 5: Results of the multi-criteria evaluation of theatres in the Czech Republic and Poland in one common file

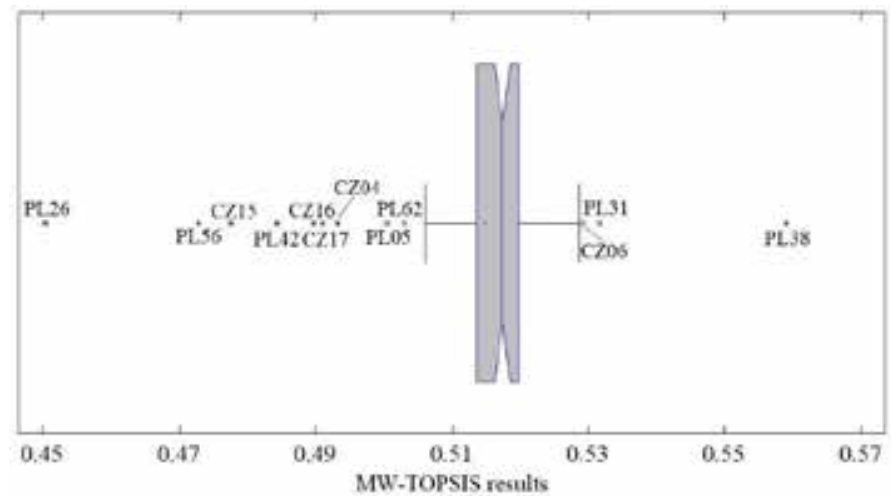

Source: Authors.

Figure 6: Multi-criteria evaluations of public theatres in the Czech Republic and Poland

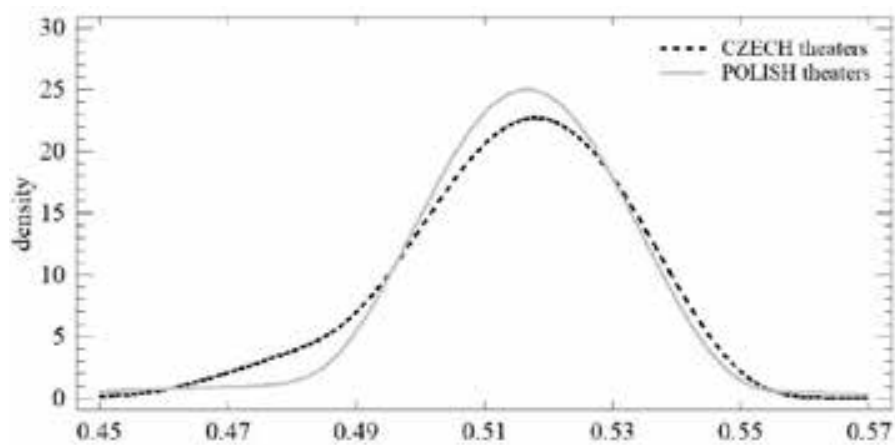

Source: Authors

From the statistical point of view, differences between the groups of Czech and Polish theatres were not proven. We can state conformity by the mean $(\mathrm{W}=758 ; \mathrm{p}=0.335)$, distribution function $(\mathrm{K}-\mathrm{S}=0.263 ; \mathrm{p}=$ $0.148)$, and also variance $(\mathrm{LE}=1.356 ; \mathrm{p}=0.247)$, i.e. research hypothesis (RH2) is confirmed. Possible differences can be attributed only to the results of individual theatres and not to the conditions at the level of evaluated states, i.e. Poland and the Czech Republic.

Most publicly established theatres are left to local authorities (municipalities and regions) in both states. Neither in the Czech Republic nor 
in Poland do optimal and uniform rules exist for funds redistribution between different theatres from public resources and within the professional public. It is still discussed whether culture should be funded and founded by local government or the centre, i.e. at the state level. Besides, despite the division of cultural institutions operated by state or local authorities (regions, municipalities), state founders did not show better results.

\section{Discussion}

The above characterised and evaluated theatrical production is developed in both states (Poland and the Czech Republic), as evidenced by the large number of operated scenes and theatre visito above the European standard. The total number of theatres is rather above standards in both states due to the number of inhabitants, with theatre entities being deployed quite equally when compared to other European countries. However, the genres offered are rather uneven in both evaluated states. A specificity of the Czech theatre infrastructure is the so-called metropolitan aspect of theatres, which is a high concentration of theatres of different genres in the metropolis (Prague). Within Czech theatrical productions, the exclusive position of the capital Prague and other large cities such as Brno, Ostrava, and Plzeň can be noted. Within Polish municipalities, the metropolitan aspect is not as pronounced as in the Czech Republic, which is caused by the eight times larger number of municipalities with over one hundred thousand inhabitants, of which there are around 40 in Poland.

Evaluation and comparison of the socio-economic benefit of the cultural sector with other industrial fields within the national economy is the current trend of modern society (Throsby, 2004). UNESCO (2012) and Chiaravalloti (2014) state that an assessment of the economic importance of organisations in culture may be carried out in different ways, contexts and approaches. Ardielli and Bečica (2018) state that, from an economic viewpoint, providing public goods is often linked to externalities and inefficiency.

According to Bernard and colleagues (2012), when funding culture, social interest in the production of certain cultural goods should be considered. An economist - a politician who takes charge of the administration of budget chapters at the relevant government level (states, regions, municipalities) - must try to ensure the requested quantity of funds after granting a political decision to fund a certain cultural field. Škarabelová, 
Neshybová and Rektořik (2007) state that cultural institutions are understood as holders of cultural activities or services and goods, and they may be classified as the final provider of cultural goods and services. Some questions in this area are, e.g. how much funding needs to be secured in a given period, how the funds will be provided, how to ensure maximum efficiency of funds, or how the priorities will be set for using funds when funding of specific kinds of produced cultural goods is decided according to the territory.

It can be stated, regardless of the selected model of evaluation, that numerous difficulties arise when providing theatrical art within a cultural field by publicly established theatres in Poland and the Czech Republic. Among the unrated in the paper, we can name the following: increasing the number and quality of realised cultural occasions provided by public resources, a persistent unsatisfactory financial situation of most publicly established institutions reflected in buildings becoming obsolete and the deterioration of technical parameters of evaluated theatres. Theatres are largely dependent on allocated funds from public resources when making art in both evaluated countries. They are distributed according to fragmented and often non-transparent criteria. Furthermore, it is possible to confirm significant differences among institutions at the level of individual indicators (i.e. also confirm RH1a in the Czech Republic but not RH1b in Poland). Ensuring goods of cultural value, as an accepted price of the entrance fee, is directly influenced by government institutions and a general lack of resources. A problem in providing cultural services in Poland is also the low number of professional actors or singers for permanent employment in the theatre industry.

Management of theatres in Poland as well as in the Czech Republic also witnesses the problem of funding their activity in the absence of uniform rules for redistribution of funds and the prevailing funding through shorttime (one-year most often) grants that do not allow for the development of long-term visions and conceptions of development of the institution adequately.

From the viewpoint of the management's approach to operating the genres of theatres, it can be stated that it is more difficult to financially secure the operation of multi-ensemble theatres. These are usually multi-genre oriented (drama, opera, ballet, musical), and their budget is several times higher than that of one-ensemble, with narrowly focused theatres prevailing in both states. This is also confirmed by the results obtained within the evaluated group of Czech theatres, but RH1 as one result cannot be confirmed for Czech and Polish theatres. One-genre theatres most often 
offer drama or puppet performances, and they performed better in the evaluation of both countries. There is evidently an effort by the institution management to generate funds from other public and private resources and not to rely only on public resources of theatre founders (municipalities, regions) in both states. Other management tasks can be stated as follows: an effort to keep, and increase, the number of visitors, to keep the variety of realised performances and selections of plays that are attractive and affordable for as many visitors as possible.

\section{Conclusion}

Theatres in European countries are usually and mainly financed using public resources at different government levels (states, regions, municipalities). This system reflects the founders and donors' willingness to keep and fund those cultural goods demanded by a larger number of visitors on the market. Currently, the management of every professional theatre in Poland and the Czech Republic has been in an unenviable situation for a long time, which is multiplied by the current pandemic.

On one hand, there is an effort to operate theatres professionally, usually based on long-term declared art and economic plans; on the other, it is necessary to use the available financial resources very effectively. Research hypothesis 2 (RH2) showed that the Czech Republic did not differ significantly from Poland in setting up public theatres, so we can confirm this hypothesis. It limited the amount of funds provided by local authorities and central elected bodies within public theatrical activities in both evaluated states, which is problematic. There is agreement among politicians, i.e. elected representatives at different government levels, on providing a number of cultural goods for inhabitants in the current conditions. For the same reason, the number of institutions funded from public resources is higher than the number of cultural institutions from private resources (not just theatres but also museums, galleries and libraries). Private funding is represented only by the founder's regulated entrance fee and presents or sponsorship by natural and legal persons; it plays a marginal role in the total amount of funds needed by publicly established cultural institutions.

In previous times, theatre reflected the political and social situation during a certain stage of development in human history and was an effective tool to refer to social reality. Theatre and theatrical art changed in Poland 
and the Czech Republic after the totalitarian regime ended in the 1990s, and it is no longer a tool used by politicians to affect social perception. However, theatre has always had and will have an irreplaceable role in man's education, cultural self-determination and realisation of reality. This is not possible without funds from public or private resources and monitoring and identifying their efficiency.

\section{References}

Aouadni, S., Rebai, A., \& Turskis, Z. (2017). The meaningful mixed data TOPSIS (TOPSIS-MMD) method and its application in supplier selection. Studies in Informatics and Control, 26(3), 353-363, https://doi.org/10.24846/ v26i3y201711

Ardielli, E., \& Bečica, J. (2018). Multi-criteria evaluation of the state of professional theatres in the Czech Republic in terms of mixed public goods provided to the citizens. Review of Economic Perspectives, 18(2), 155-176, https://doi. org/10.2478/revecp-2018-0009

Badia, F., \& Borin, E. (2012). Opportunities and critical points for the introduction of performance measurement systems in theatres - a comparison between theoretical assumptions and empirical realities. Journal of Cultural Management and Policy, 2(2), 45-59.

Bečica, J. (2018). Income self-sufficiency and profitability of professional theatres in the Czech Republic. Review of Economic Perspectives, 18(3), 285-299, http:// doi.org/10.2478/revecp-2018-0014

Bernard, J., Patočková, V., Čermák, D., \& Vojtíšková, K. (2012). Kultura v krajich České republiky. [Culture in the regions of the Czech Republic]. Prague, Czech Republic: Institute of Sociology.

Cai, Z., \& Wang, Y. (2012). Research frontiers in public sector performance measurement. Physics Procedia, 25, 793-799, https://doi.org/10.1016/j. phpro.2012.03.159

Čereška, A., Zavadskas, E. K., Bucinskas, V., Podvezko, V., \& Sutinys, E. (2018). Analysis of steel wire rope diagnostic data applying multi-criteria methods. Applied Sciences, 8(2), 260, https://doi.org/10.3390/app8020260.

Charles, C., \& Kim, M. (2016). Do donors care about results? An analysis of nonprofit arts and cultural organizations. Public Performance \& Management Review, 39(4), 864-884, https://doi.org/10.1080/15309576.2015.1137775

Chiaravalloti, F. (2014). Performance evaluation in the arts and cultural sector: A story of accounting at its margins. The Journal of Arts Management, Law and Society, 44(2), 61-89, https://doi.org/10.1080/10632921.2014.905400

Dostál, P., \& Kislingerová, E. (2012). Ekonomika kultury: efektivní metody a nástroje podnikáni v sektoru kultury [Economics of culture: Effective methods and tools of business in the cultural sector]. Prague, Czech Republic: Oeconomica. 
Dvořák, J. (2004). Kreativni management pro divadlo, aneb, O divadle jinak: kapitoly $k$ tématu realizace divadla. [Creative management for theatre, or, About theatre differently: chapters on the topic of theatre realisation]. Prague, Czech Republic: Pražská scéna.

Galecka, M., \& Smolny, K. (2019). Criteria for the optimal financing model of public theatres. Review of Economic Perspectives, 19(2), 119-136, https://doi. org/10.2478/revecp-2019-0007

Guarini, M. R., Battisti, F., \& Chiovitti, A. (2018). Public initiatives of settlement transformation: A theoretical - methodological approach to selecting tools of multi-criteria decision analysis. Buldings, 8(1), https://doi.org/10.3390/buildings 8010001

Hashemkhani Zolfani, S., Pourhossein, M., Yazdani, M., \& Zavadskas, E. K. (2018). Evaluating construction projects of hotels based on environmental sustainability with MCDM framework. Alexandria Engineering Journal, 57(1), 357-365, https://doi.org/10.1016/j.aej.2016.11.002

Keršuliene, V. Zavadskas, E. K., \& Turskis, Z. (2010). Selection of rational dispute resolution method by applying new step-wise weight assessment ratio analysis (SWARA). Journal of Business Economics and Management, 11(2), 243-258, https://doi.org/10.3846/jbem.2010.12

Musgrave, R. A. (1959). The theory of public finance. New York, USA: McGraw-Hill.

National Information and Advisory Centre for Culture (2015). Kultura České republiky v čislech: vybrané údaje ze statistických šetřeni [Culture of the Czech Republic in numbers: Selected data from statistical surveys]. Prague, Czech Republic: Národní informační a poradenské středisko pro kulturu.

Noryani, M., Sapuan, S. M., \& Mastura, M. T. (2018). Multi-criteria decision-making tools for material selection of natural fibre composites: A review. Journal of Mechanical Engineering and Sciences, 12 (1), 3330-3353, https://doi. org/10.15282/jmes.12.1.2018.5.0299

Pareto, V., \& Schwier, A. S. (1927). Manual of political economy. New York, USA: A.M. Kelley Pubs.

Peková, J. (2011). Veřejné finance: teorie a praxe v ČR [Public finance: Theory and practice in the Czech Republic]. Prague, Czech Republic: Wolters Kluwer ČR.

Pestoff, V. A. (1992). Third sector and co-operative services - An alternative to privatization. Journal of Consumer Policy, 15, 21-45, https://doi.org/10.1007/ bf01016352

Samuelson, P. A. (1954). The pure theory of public expenditure. The Review of Economics and Statistics, 36(4), 387-389, https://doi.org/10.2307/1925895

Samuelson, P. A., \& Nordhaus, W. D. (2010). Economics. New York, USA: McGraw Hill.

Seyedmohammadi, J., Sarmadian, F., Jafarzadeh, A. A., Ghorbani, M. A., \& Shahbazi, F. (2018). Application of SAW, TOPSIS and fuzzy TOPSIS models in cultivate on priority planning for maize, rapeseed and soybean crops. Geoderma, 310, 178-190, https://doi.org/10.1016/j.geoderma.2017.09.012 
Shih, H. S., Shyur, H. J., \& Lee, E. S. (2007). An extension of TOPSIS for group decision making. Mathematical and computer modelling, 45(7-8), 801-813, https://doi.org/10.1016/j.mcm.2006.03.023

Singla, A., Ahuja, S. I., \& Sethi, A. S. (2018). Comparative analysis of technology push strategies influencing sustainable development in manufacturing industries using TOPSIS and Vikor technique. International Journal for Quality Research, 12(1), 129-146, https://doi.org/ 10.18421/IJQR12.01-08

Škarabelová, S., Neshybová, J., Rektořík, J. (2007). Ekonomika kultury a masmédií [Economics of culture and mass media]. Brno, Czech Republic: Masaryk University.

Stiglitz, J. E. (1997). Ekonomie veřejnébo sektoru [Public sector economics]. Prague, Czech Republic: Grada Publishing.

Stiglitz, J. E., \& Rosengard, J. K. (2015). Economics of the public sector. New York, USA: W. W. Norton Company.

Throsby, D. (2004). Assessing the impacts of a cultural industry. Journal of Arts Management, Law and Society, 34(3), 188-204, https://doi.org/10.3200/ JAML.34.3.188-204

UNESCO Institute for Statistics. (2012). Measuring the economic contribution of cultural industries. A review and assessment of current methodological approaches. Retrieved from https://unesdoc.unesco.org/ark:/48223/pf0000218251

Vavrek, R. (2019). Evaluation of the Impact of Selected Weighting Methods on the Results of the TOPSIS Technique. International Journal of Information Technology \& Decision Making, 18(6), 1821-1843, https://doi.org/10.1142/ S021962201950041X

Vavrek, R., \& Bečica, J. (2020a). Efficiency evaluation of cultural services in the Czech Republic via multi-criteria decision analysis. Sustainability, 12(8), 3409, https://doi.org/10.3390/su12083409

Vavrek, R., \& Bečica, J. (2020b). Capital City as a Factor of Multi-Criteria Decision Analysis-Application on Transport Companies in the Czech Republic. Mathematics, 8(10), 1765, https://doi.org/10.3390/math8101765

Vrabková, I., Vaňková, I., Bečica, J., \& Kryšková, Š. (2017). Př́spěvkové organizace: postavení, úkoly a technická efektivnost [Contributory organisations: Position, tasks and technical efficiency]. Ostrava, Czech Republic: VŠB-TU Ostrava.

Wang, S. J. X., \& Poh, K. L. (2017). Intelligent decision support in proportional-stop-loss reinsurance using multiple attribute decision-making (MADM). Journal of Risk and Financial Management, 10(4), https://doi.org/10.3390/ jrfm10040022

Zavadskas, E. K., Antucheviciene, J., Vilutiene, T., \& Adeli, H. (2018). Sustainable decision-making in civil engineering, construction and building technology. Sustainability, 10(1), https://doi.org/10.3390/su10010014

Zavadskas, E. K., Mardani, A., Turskis, Z., Jusoh, A., \& Nor, K. (2016). Development of TOPSIS method to solve complicated decision-making problems: An overview on developments from 2000 to 2015. International Journal of Information Technology \& Decision Making, 15, 1-38, https://doi.org/10.1142/ S0219622016300019 


\section{Legal sources}

Act on Organising and Running Cultural Activities, Journal of Laws, 114/493

\section{Appendix A}

List of evaluated theatres from the Czech Republic (26) and Poland (67).

\begin{tabular}{|l|l|}
\hline \multicolumn{2}{|l|}{ Czech Republic } \\
\hline CZ01 & Centrum experimentálního divadla in Brno \\
\hline CZ02 & Divadlo ALFA in Plzeň \\
\hline CZ03 & Divadlo F.X. Šaldy in Liberec \\
\hline CZ04 & Divadlo J.K. Tyla in Plzeň \\
\hline CZ05 & Divadlo Na zábradlí in Prague \\
\hline CZ06 & Divadlo A. Dvořáka Př́bram \\
\hline CZ07 & Horácké divadlo Jihlava \\
\hline CZ08 & Jihočeské divadlo in České Budějovice \\
\hline CZ09 & Divadlo Radost in Brno \\
\hline CZ10 & Městská divadla pražská \\
\hline CZ11 & Městské divadlo Brno \\
\hline CZ12 & Městské divadlo Zlín \\
\hline CZ13 & Moravské divadlo Olomouc \\
\hline CZ14 & Naivní divadlo Liberec \\
\hline CZ15 & Národní divadlo in Brno \\
\hline CZ16 & Národní divadlo moravskoslezské in Ostrava \\
\hline CZ17 & Národní divadlo in Prague \\
\hline CZ18 & Slezské divadlo in Opava \\
\hline CZ19 & Slovácké divadlo in Uherské Hradiště \\
\hline CZ20 & Těśínské divadlo in Český Těšín \\
\hline CZ21 & Východočeské divadlo Pardubice \\
\hline CZ22 & Západočeské divadlo in Cheb \\
\hline CZ23 & Dejvické divadlo in Prague \\
\hline CZ24 & Divadlo Drak a Mezinárodní institut figurálního divadla in Hradec Králové \\
\hline CZ25 & Klicperovo divadlo in Hradec Králové \\
\hline CZ26 & Severočeské divadlo in Ústí nad Labem \\
\hline
\end{tabular}




\begin{tabular}{|c|c|}
\hline \multicolumn{2}{|r|}{ Poland } \\
\hline PL01 & Teatr Polski \\
\hline PL02 & Teatr Lalek Banialuka \\
\hline PL03 & Teatr Polski im. H. Konieczki \\
\hline PL04 & Teatr im A. Mickiewicza \\
\hline PL05 & Teatr Miejski im. W. Gombrowicza \\
\hline PL06 & Śląski Teatr Lalki i Aktora "Ateneum" \\
\hline PL07 & Teatr Ludowy \\
\hline PL08 & Teatr Bagatela im. T. Boya-żeleńskiego \\
\hline PL09 & Teatr Lalki, Maski i Aktora "Groteska" \\
\hline PL10 & Teatr Łaźnia Nowa \\
\hline PL11 & Teatr im. H.Ch. Andersena \\
\hline PL12 & Teatr Nowy im. K. Dejmka \\
\hline PL13 & Teatr Powszechny \\
\hline PL14 & Teatr Lalek „Arlekin” \\
\hline PL15 & Teatr Lalki i Aktora „Pinokio” \\
\hline PL16 & Teatr Muzyczny \\
\hline PL17 & Olsztyski Teatr Lalek \\
\hline PL18 & Teatr Polski in Poznań \\
\hline PL19 & Teatr Animiacji in Poznań \\
\hline PL20 & Teatr Ósmego Dnia \\
\hline PL21 & Teatr Lalek Pleciuga \\
\hline PL22 & Teatr Współczesny in Szczecin \\
\hline PL23 & Teatr Baj Pomorski \\
\hline PL24 & Teatr Współczesny in Wrocław \\
\hline PL25 & Teatr Lalek in Wrocław \\
\hline PL26 & Capitol \\
\hline PL27 & Teatr Anateum im. S. Jaracza \\
\hline PL28 & Teatr Baj \\
\hline PL29 & Teatr Dramatyczny im. G. Holoubka \\
\hline PL30 & Teatr Lalek Guliwer \\
\hline PL31 & Północne Centrum Sztuki Teatr Komedia \\
\hline PL32 & Teatr Kwadrat \\
\hline PL33 & Teatr Lalka \\
\hline PL34 & Teatr Nowy \\
\hline PL35 & Teatr Ochoty \\
\hline
\end{tabular}




\begin{tabular}{|l|l|}
\hline PL36 & Teatr Powszechny im. Z. Hübnera \\
\hline PL37 & Teatr Rampa na Targówku \\
\hline PL38 & Teatr Muzyczny Roma \\
\hline PL39 & Teatr Rozmaitości \\
\hline PL40 & Teatr Scena Prezentacje \\
\hline PL41 & Teatr Studio im. S. I. Witkiewicza \\
\hline PL42 & Teatr Syrena \\
\hline PL43 & Teatr Współczesny in Warszawa \\
\hline PL44 & Teatr żydowski im. E., R. i I. Kamińskich \\
\hline PL45 & Opolski Teatr Lalki i Aktora im. A. Smolki \\
\hline PL46 & Teatr „Maska” in Rzeszów \\
\hline PL47 & Teatr Muzyczny im. D. Baduszkowej in Gdynia \\
\hline PL48 & Teatr Dramatyczny im. A. Węgierki in Białystok \\
\hline PL49 & Teatr Wierszalin in Supraśl \\
\hline PL50 & Teatr Polski in Szczecin \\
\hline PL51 & Teatr im. Stefana Jaracza in Olsztyn \\
\hline PL52 & Teatr im. A. Sewruka in Elbląg \\
\hline PL53 & Teatr im. S. żeromskiego in Kielce \\
\hline PL54 & Teatr Dramatyczny im. J Szaniawskiego in Płock \\
\hline PL55 & Teatr im. Stefana Jaracza in Łódź \\
\hline PL56 & Teatr Wielki in Łódź \\
\hline PL57 & Teatr Rozrywki in Chorzów \\
\hline PL58 & Teatr im. J. Słowackiego in Kraków \\
\hline PL59 & Teatr im. S. I. Witkiewicza in Zakopane \\
\hline PL60 & Teatr im. Jana Kochanowskiego \\
\hline PL61 & Teatr im Wiliama Horzycy \\
\hline PL62 & Teatr Wielki im. S. Moniuszki in Poznań \\
\hline PL63 & Teatr Nowy im. Tadeusza Łomnickiego in Poznań \\
\hline PL64 & Teatr im A. Fredry in Gniezno \\
\hline PL65 & Teatr im. W. Bogusławskiego in Kalisz \\
\hline PL66 & Teatr im. Jana Osterwy in Gorzów Wlk. \\
\hline
\end{tabular}




\section{APPLICATION OF MULTI-CRITERIA ANALYSIS ON THEATRES' EFFICIENCY - CZECH AND POLISH COMPARATIVE CASE STUDIES}

\section{Summary}

Culture is a means of transferring information between generations. We include the field of interpretive culture into a cultural branch that is usually non-profit in democratic states with a market-driven economy. The aim of this study is to identify the efficiency of 93 public theatres' management in Poland and the Czech Republic in 2015 using 5 technical and 6 financial indicators. The evaluated indicators are processed using the Technique for Order of Preference by Similarity to Ideal Solution (TOPSIS), in combination with a chosen objective method for determining indicators' importance, i.e. the Mean Weight method. Within the paper, Czech theatres were evaluated first, then Polish theatres followed by an evaluation of both in one file. According to the results, it is evident that the bigger multi-genre theatres in the Czech Republic producing more genres of interpretive art (drama, opera, ballet, musical) with a bigger number of employees, had the worst results. Most publicly established theatres are left to local authorities (municipalities and regions) in both states. Neither in Poland nor in the Czech Republic do optimal and uniform rules exist for fund redistribution between different theatres from public resources and within the professional public. It is still discussed whether culture should be funded and founded by the local government or from the centre, i.e. at the level of states. In addition, despite the division between cultural institutions operated by state or local authorities (regions, municipalities), state founders did not provide better results. Fundamental differences in the functioning of publicly established theatres in Poland and the Czech Republic were not proved in the evaluation.

Keywords: culture, public goods, theatres, MCDM methods, TOPSIS, international comparison 


\section{PRIMJENA VIŠEKRITERIJSKE ANALIZE NA UČINKOVITOST KAZALIŠTA - KOMPARATIVNA STUDIJA SLUČAJEVA U ČEŠKOJ I POLJSKOJ}

\section{Sažetak}

Kultura je sredstvo prijenosa informacija izmedu generacija. $U$ radu se primjenjuju pogledi interpretativne kulture na granu kulture koja je u državama s tržǐsnim gospodarstvom uglavnom neprofitna. Cilj je te studije izmjeriti učinkovitost upravljanja u 93 javna kazališta u Poljskoj i Češkoj Republici u 2015. godini koristeći se $s$ pet tehničkib $i$ šest financijskib indikatora. Evaluirani indikatori obradeni su metodom TOPSIS (Technique for Order of Preference by Similarity to Ideal Solution) u kombinaciji s metodom odabranog cilja za odredivanje važnosti pojedinih indikatora. U radu su prvo evaluirana kazališta u Češkoj, zatim ona u Poljskoj te naposlietku sva usporedno u jednom dokumentu. S obzirom na rezultate, evidentno je da kazališta u Češkoj, kao ona koja su veća, $s$ više zaposlenib te se kao višežanrovska bave većim brojem scenskib umjetnosti (drama, opera, balet, mjuzikl) bilježe lošije rezultate. U objema državama većinom jarnib kazališta upravljaju lokalne i/ili regionalne vlasti. Ni u Poljskoj ni u Češkoj ne postoje jasna $i$ ujednačena pravila o financiranju kazališta $i$ distribuciji novčanih sredstava među kazalištima. Još se vode rasprave bi li kulturu trebale financirati subnacionalne samoupravne razine ili središnje državne vlasti. Unatoč podjeli kulturnib institucija na one kojima upravlja država i na one kojima upravljaju lokalne $i$ regionalne jedinice, državne institucije nisu zabilježile bolje rezultate. Također, temeljne nacionalne razlike u funkcioniranju javnib kazališta između Poljske $i$ Češke nisu se pokazale bitnima u evaluaciji njibove učinkovitosti.

Ključne riječi: kultura, javna dobra, MCDM metoda, TOPSIS, medunarodna usporedba 